\title{
PENGARUH POLITIK DALAM PERKEMBANGAN PRAKTIK EKONOMI ISLAM DI INDONESIA
}

\section{Nur Kholis}

Dosen UII yang saat ini diamanahi sebagai Ketua Prodi Ekonomi Islam FIAI UII. Penulis juga pengurus MES (Masyarakat Ekonomi Syariah) DIY, bidang syariah compliance dan anggota BASYARNAS DIY.

email: nurkholisyes@gmail.com

\section{ABSTRACT}

The article below attempt to analize the influence of Indonesian politics to the development of islamic economics practices in Indonesia, especially situation and condition of Indonesian politics in the New Order Era and the reformation era. The article find that the influence of situation and condition of politics transformed in Indonesian political economy oriented to Islamic economic system in developing Islamic economic practice is very signifinace. Politics of the New Order Era bounded the development of Islamic economic practice. Politics of the reformation era supported the development of Islamic economic practice. It was proven by a rapid progress of Islamic economicpractice in the area of Islamic banking, Islamic insurance, Islamic capital market, Sukuk, Islamic unit trust/mutual fund, Islamic microfinance institution, and Islamic public finance in the reformation era because of political condition and situation support.

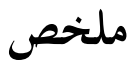

هذه المقالة تحاولأن تحلل تأثير السياسة الإندونيسية إلى تطوير ممارسات الاقتصاد الإسلامي في إندونيسيا، وخصوصا الوضع والحالة من السياسة الإندونيسية فيعصر النظام الجحيد وعصر الإصلاح. تبحدالمقالة أن تأثير الوضع والحالة من تحول السياسة في الاقتصاد السياسي الإندونيسي الموجه إلى النظام الاقتصادي الإسلامي في تطوير الممارسة الاقتصادية الإسلامية هو مهم جدا. السياسة فيعصر النظام الجمديدتحدد تطوير الممارسة الاقتصادية الإسلامية. السياسة في عصر الإصلاح تدعم تطوير 


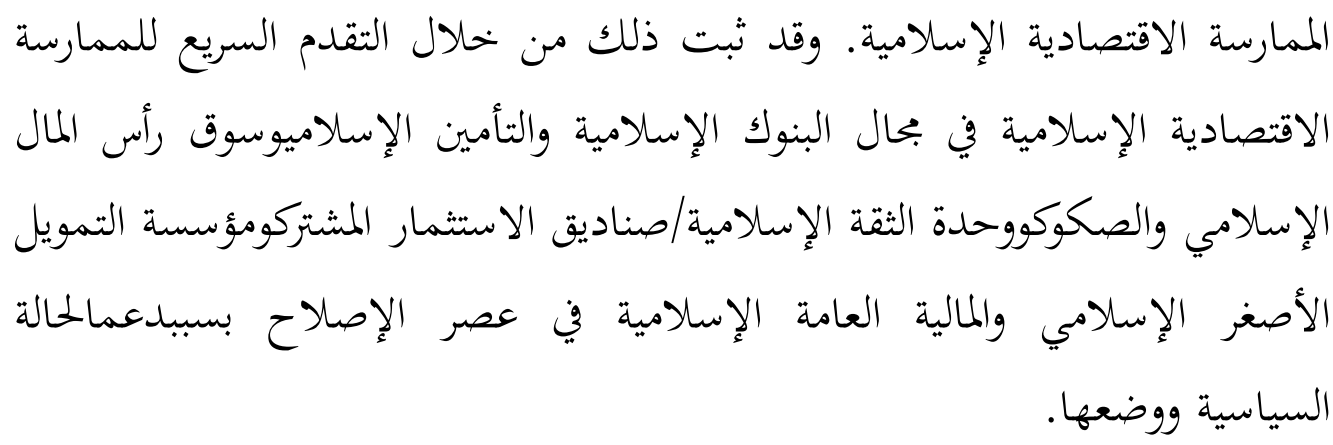

Key words: politik, era Orde Baru, era Reformasi, ekonomi Islam, dan pemerintah RI.

\section{A. Pendahuluan}

Politik dan ekonomi adalah entitas yang tidak bisa terpisahkan, satu sama lain saling mempengaruhi. Dinamika hubungan politik dan ekonomi telah menjadi perhatian banyak peneliti di dunia. Perubahan politik akan berpengaruh terhadap kehidupan ekonomi. Sebaliknya kehidupan ekonomi berpengaruh terhadap kehidupan politik. ${ }^{1}$ Hal ini sebagaimana juga dinyatakan oleh mantan Menteri Keuangan Chili, Alejandro Foxley, sebagaimana dikutip dalam Williamson dan Haggard (1994). Beliau menegaskan bahwa Economists must not only know their economic models, but also understand politics, interests, conflicts, passions - the essence of collective life. For a brief period of time you could make changes by decree; but to let them persist, you have to build coalitions and bring people around. You have to be a politician. ${ }^{2}$

Di sisi lain, pemahaman yang baik terhadap proses dan mekanisme politik, sangat menentukan keberhasilan sebuah gagasan ataupun sebuah ideologi ekonomi dalam menciptakan sistem perekonomian yang menjadikan nilai (value) yang dibawa oleh gagasan atau ideologi tersebut sebagai pondasi utamanya. Prof Zubair Hasan, peraih penghargaan IDB Prize dalam bidang ekonomi Islam tahun 2009, dalam berbagai kesempatan menyatakan bahwa seandainya setiap

1 Torsten Persson dan Guido Tabellini, 2006, Democratic Capital: The Nexus Of Political And Economic Change, Massachusetts: NBER Working Paper Series, Working Paper 12175, http://www.nber.org/papers/w12175

2 Dikutip oleh Irfan Syauqi Beik dalam http://jurnalekis.blogspot.com/2013/01/desain-politik-ekonomi-syariah.html\#sthash.zgeRsgDl.dpuf, diakses 5 Juli 2013 
pemerintah (negara-negara anggota OKI/Organisasi Konferensi Islam) menjadikan ekonomi Islam sebagai dasar perumusan kebijakan perekonomian mereka, maka perkembangan ekonomi Islam belum akan bisa menyaingi ekonomi konvensional. Dengan kata lain, beliau menegaskan pentingnya mendorong keberpihakan kekuasaan terhadap pengembangan ekonomi Islam secara keseluruhan, sehingga dominasi ekonomi yang berbasis riba dapat diminimalisir.

Secara implisit, pernyataan Prof Zubair Hasan tersebut juga bermakna bahwa keputusan politik negara memiliki pengaruh yang sangat kuat terhadap kondisi perekonomian suatu bangsa. Wajah dan kinerja ekonomi sebuah negara, sangat ditentukan oleh mekanisme dan proses pengambilan keputusan politik yang berlaku dan disepakati oleh masyarakat di negara tersebut. Oleh karena itu, dalam konteks Indonesia, perlu dikaji bagaimana pengaruh situasi dan kondisi politik yang merupakan konsekuensi dari keputusan politik penguasa pada masanya berpengaruh terhadap perkembangan praktik ekonomi Islam di Indonesia. Paper ini akan mengkaji hal tersebut dengan fokus pada situasi perpolitikan di era Orde Baru dan era Orde Reformasi.

\section{B. Politik dan Ekonomi}

Kajian tentang hubungan antara politik dan ekonomi telah sangat banyak. ${ }^{3} \mathrm{Ke}-$ matangan berpolitik suatu negara selalu berhubungan erat dengan kemajuan ekonominya. Kemajuan ekonomi menopang terwujudnya situasi dan kondisi politik yang stabil, sebaliknya kondisi politik yang stabil akan menunjang terwujudnya kehidupan berekonomi yang maju dan mensejahterakan. Oleh karena itu, jika situasi politik kondusif, maka perekonomian dan bisnis secara umum akan berjalan dengan lancar. Dari segi pasar saham, situasi politik yang kondusif akan membuat harga saham naik. Sebaliknya, jika situasi politik ti-

3 Diantaranya Torsten Persson dan Guido Tabellini, 2006, Democratic Capital: The Nexus Of Political And Economic Change, Massachusetts: NBER Working Paper Series, Working Paper 12175, http://www.nber.org/papers/w12175.; Acemoglu and Daron, dkk (2005), Income and Democracy, Mimeo, MIT.; Acemoglu, Daron and Robinson (2005), Economic Origins of Dictatorship and Democracy, Cambridge University Press; Robert Barro (1996), "Democracy and Growth", Journal of Economic Growth 1, 1-27 Helliwell, John. (1994). "Empirical Linkages Between Democracy and Economic Growth", British Journal of Political Science 24, 225-248. 
dak menentu, maka akan menimbulkan unsur ketidakpastian dalam bisnis. Perubahan suhu politik akibat dari suatu tindakan maupun kebijakan politik di suatu negara dapat menimbulkan dampak besar pada perekonomian negara tersebut. Risiko politik umumnya berkaitan erat dengan pemerintahan serta situasi politik dan keamanan di suatu negara.

Dalam konteks itu, kinerja sistem ekonomi-politik sudah berinteraksi satu sama lain, yang menyebabkan setiap peristiwa ekonomi-politik tidak lagi dibatasi oleh batas-batas tertentu. Misalnya, IDB (Islamic Development Bank), IMF (International Monetary Fund), atau Bank Dunia (World Bank), atau bahkan para investor asing selalu mempertimbangkan peristiwa politik nasional dan mengkalkulasi risikonya secara ekonomi dan bisnis.

Pola politik juga selalu berkait erat dengan perkembangan bisnis. Sebaliknya pola bisnis juga senantiasa berkait erat dengan politik. Budaya politik merupakan serangkaian keyakinan atau sikap yang memberikan pengaruh terhadap kebijakan dan administrasi publik di suatu negara, termasuk di dalamnya pola yang berkaitan dengan kebijakan ekonomi atau perilaku bisnis.

Dalam konteks peran politik terhadap ekonomi dan bisnis, terdapat sistem politik yang dirancang untuk menjauhkan campur tangan pemerintah dalam bidang perekonomian dan bisnis, yaitu sistem liberal. Ada juga sistem politik yang bersifat intervensionis secara penuh terhadap perekonomian dan bisnis. Ada pula sistem politik yang cenderung mengarahkan agar pemerintah terlibat dan ikut campur tangan dalam bidang ekonomi bisnis. Indonesia lebih mengacu pada pola terakhir, yakni pemerintah terlibat atau turut campur tangan dalam ekonomi dan bisnis. Hal ini dapat dilihat dalam hukum maupun kebijakan-kebijakan yang dikeluarkan pemerintah untuk menunjang perekonomian dan bisnis. Kebijakan pemerintah RI berpengaruh siginifikan terhadap perkembangan ekonomi dan bisnis.

\section{Politik Era Orde Baru dan Ekonomi Islam}

Keluarnya Surat Perintah 11 Maret 1966 merupakan titik awal lahirnya Orde Baru. ${ }^{4}$ Naiknya Soeharto menjadi orang nomor satu di Indonesia secara resmi

4 Maswadi Rauf, "Kata Pengantar" dalam buku yang ditulis oleh Ahmad Suhelmi, Soekarno Versus Natsir, (Jakarta: Darul Falah, 1999), hal. X. Lihat pula Marwati Poesponegoro dan Nugroho Notosusanto, Sejarah Nasional Indonesia, Jilid VI (Jakarta: Depdikbud dan Balai 
pada Maret 1968 menandai pudarnya pamor dua kekuatan politik utama dalam Orde Lama dari percaturan politik nasional, yaitu Soekarno dan PKI, dengan meninggalkan ABRI sebagai kekuatan politik seorang diri. Pada saat itu berarti ABRI memiliki surplus of power untuk berbuat apa saja, termasuk kudeta untuk membentuk pemerintahan junta militer. ${ }^{5}$ Namun ternyata peluang itu tidak "dimanfaatkan" ABRI. Hal ini karena tiga faktor: pertama, sikap perwira militer Jawa sangat dipengaruhi oleh orientasi dan budaya politik Jawa, misalnya penghormatan terhadap "Bapak" Soekarno. Kedua, sikap legalistik A.H. Nasution. Ketiga, pertimbangan apa yang paling baik bagi kepentingan nasional. ${ }^{6}$

Persoalan pokok yang dihadapi oleh Indonesia pada awal-awal rezim Orde Baru adalah warisan krisis dari rezim sebelumnya, yaitu krisis politik dan ekonomi yang begitu parah. ${ }^{7}$ Di bidang ekonomi terjadi kemerosotan dan stagnasi. Pada tahun 1966 laju inflasi mencapai $650 \% .{ }^{8}$ Sementara di bidang politik, terjadi instabilitas karena terjadinya pertentangan antar kelompok-kelompok politik dalam masyarakat.

Keadaan politik di Indonesia menjelang lahirnya Orde Baru ditandai dengan enam ciri, ${ }^{9}$ yaitu: kegagalan sistem multi partai; percaturan politik yang bertumpu pada dasar partai ideologi dalam suasana masyarakat yang belum menghayati aturan permainan politik yang ada; perpecahan birokrasi karena campur tangan partai dalam birokrasi dan menjadikan birokrasi sebagai asasnya; partai politik menggunakan corak partai "totalitarian"; penyusupan PKI dalam ABRI sehingga menimbulkan disharmoni di dalam tubuh ABRI; terjadinya konflik interpersonal di tingkat grassroot (akar rumput/rakyat jelata) akibat dari interaksi interpersonal yang didasarkan pada nilai-nilai primordial,

Pustaka, 1984), hal. 406

5 Al Chaidar, Reformasi Prematur Jawaban Islam Terhadap Reformasi Total, (Jakarta: Darul Falah, 1999), hal. 27

6 Abdul Aziz Thaba, Islam dan Negara dalam Politik Orde Baru, (Jakarta: Gema Insani Press, 1996), hal. 196

7 Moh. Mahfud MD, Hukum dan Pilar-Pilar Demokrasi, (Yogyakarta: Gama Media, 1999), hal. 206

8 Parahnya keadaan perekonomian pada masa ini bisa dicermati pada Anna Both dan Peter Melawley, Ekonomi Orde Baru, (Jakarta: LP3ES, 1981)

9 Moeljarto Tjokrowinoto, Pembangunan Dilema dan Tantangannya, (Yogyakarta: Pustaka Pelajar, 1996), hal. 104-105 dan 203-211 
orientasi "parokhial" dan hubungan "patron-klien". ${ }^{10}$

Dalam konteks yang lebih luas, Professor Donald Wilson mengkalkulasi ada sembilan permasalahan yang dihadapi Orde Baru pada awal-awal pemerintahannya, khususnya yang berhubungan dengan aspek ekonomi yaitu: (1). Pembentukan suasana stabilitas politik dan sosial (keamanan bangsa) yang memungkinkan terjadinya perubahan. (2). Menciptakan satu bangsa yang terhindar dari perpecahan umat dan banyaknya bahasa dan dialek yang bisa menggoncangkan. (3). Membawa rakyat untuk berada bersama-sama di dalam pemerintahan, yaitu mereka yang bukan hanya penurut saja, atau ABS (Asal Bapak Senang), mereka yang memiliki kemampuan dan kepakaran khusus guna menangani masalah bangsa dan negara secara cerdik dan arif. (4). Menghapuskan kelembapan dan buck passing (menghindarkan tanggungjawab) yang melumpuhkan pemerintahan begitu lama. (5). Membentuk suatu semangat kerjasama di dalam pemerintahan yang bisa menafikan kecemburuan dan perbedaan yang bersifat primordial (kedaerahan maupun kesukuan). (6). Menjauhkan kepentingan pribadi dan sakit hati mereka yang sangat menginginkan untuk kembali ke era Soekarno. (7). Menangani masalah-masalah ekonomi dan pembangunan ekonomi serta menghindari keruntuhan ekonomi. (8). Membangun kemandirian (self sufficiency) pertanian untuk memenuhi keperluan pangan. (9). Memperoleh lebih banyak lagi pengadilan yang adil. ${ }^{11}$

Untuk mengatasi krisis yang dihadapi, pemerintahan Orde Baru mengambil kebijakan yang difokuskan pada bidang ekonomi dan bidang politik yang mampu mendukung pembangunan ekonomi. Kebijakan ini berbeda dengan kebijakan yang diambil Orde Lama. Kalau pada masa Orde Lama pembangunan ditekankan pada bidang politik, maka Orde Baru mengubahnya menjadi ekonomi. Jargon politik no, ekonomi yes seringkali disuarakan pada awal-awal pemerintahan Orde Baru. ${ }^{12}$

${ }_{10}$ Hubungan patron-client dalam bahasa Indonesia diterjemahkan menjadi "induk semang-klien". Hubungan ini mengacu pada hubungan saling ketergantungan antara seseorang dengan bawahannya. Koentjaraningrat, "Mentalitas Pegawai, Feodalisme, dan Demokrasi", dalam Tim KAHMI JAYA, Jika Rakyat Berkuasa Upaya Membangun Masyarakat Madani dalam Kultur Feodal, (Bandung: Pustaka Hidayah, 1999), hal. 154

11 Deskripsi permasalahan ini dikutip oleh Sudarsono, Politik dan pembangunan: Pilihan Masalah (Jakarta: Rajawali Press, 1980), hal. 25

12 Maswadi Rauf, op. cit., hal. $\mathrm{x}$ 
Upaya "pengordebaruan" juga berlangsung dalam hal orientasi pemikiran sosial politik dan ekonomi, yang pada masa Orde Lama tekanannya sangat ideologis dan politis. Oleh karena itulah para pendukung Orde Baru menciptakan pemikiran-pemikiran tandingan (counter ideas), sehingga muncullah ide-ide pragmatik, deideologisasi, deparpolisasi, pembangunan oriented, dan lainlain. ${ }^{13}$

Dari sini Orde Baru pernah berjanji atau memberikan jaminan untuk menyelamatkan stabilitas ekonomi dan politik, meningkatkan kesejahteraan rakyat. Bagi rezim Orde Baru terjaminnya ekonomi rakyat menjadi sumber bagi legitimasinya dalam menjalankan roda pemerintahan. ${ }^{14}$ Bahkan menurut Grosart, sebagaimana dikutip M. Rusli Karim, para pemimpin Orde Baru beranggapan bahwa ketegangan yang ada dalam masyarakat hanya bisa dihilangkan dengan pembangunan ekonomi. ${ }^{15}$

Sasaran pembangunan ekonomi yang sangat berhubungan dengan stabilitas politik, sebenarnya sah-sah saja asalkan disejajarkan pula dengan pemberian kebebasan politik, karena pertumbuhan ekonomi hanya mungkin dicapai jika ada stabilitas politik. ${ }^{16}$ Inilah yang menjadi sasaran utama pembangunan politik sehingga tekanannya adalah pada pendekatan keamanan (security approach), bukan pendekatan kesejahteraan (prosperity approach). Fakta menunjukkan kecenderungan politik dan ekonomi diarahkan untuk memperkukuh pemerintah pusat. Kuatnya pemerintah pusat akan menjadikan pemerintah sebagai satusatunya sebagai institusi politik yang berpengaruh. ${ }^{17}$

\footnotetext{
13 Abdul Aziz Thaba, op. cit., hal. 188

14 Yahya Muhaimin, Bisnis dan Politik Kebijaksanaan Ekonomi Indonesia 1950-1980, (Jakarta: LP3ES, 1990), hal. 119.

15 M. Rusli Karim, Negara dan Peminggiran Islam Politik, (Yogyakarta: Tiara Wacana, 1999), hal. 56

16 Sudah cukup banyak kajian yang kemudian menyimpulkan bahwa ada hubungan yang erat antara tingkat perkembangan ekonomi dan tingkat partisipasi politik, misalnya kajian dilakukan oleh Rostow, Irma Adelman, dan Cynthia Taft Morris. Lihat Emil Salim, "Mungkinkah Ada Demokrasi di Indonesia", dalam Elza Peldi Taher (ed.), Demokratisasi Politik, Budaya dan Ekonomi, (Jakarta: Yayasan Paramadina, 1994), hal. 157-159

17 Sebagaimana diakui oleh Sarwono Kusumaatmadja dalam, Sketsa Politik Orde Baru, (Bandung: Alumni, 1988), hal. 38-39. Dalam kaitannya dengan kuatnya peran negara telah dibahas banyak pakar, bahkan telah muncul lebih dari 15 istilah untuk menyebutkan rezim Orde Baru. Lihat Abdul Aziz Thaba, op. cit., hal. 51-69
} 
Menurut Mac Andrews, pemerintah yang kuat diperlukan untuk menghadapi tiga tantangan yang memerlukan jawaban secepatnya. Pertama, keperluan untuk menciptakan pengawasan dan memaksakan otoritas pemerintah pusat terhadap seluruh daerah. Kedua, untuk memperbaiki kestabilan ekonomi dan meletakkan asas bagi pembangunan ekonomi. Ketiga, membangun legitimasinya sebagai sebuah rezim. ${ }^{18}$

Rezim Orde Baru dalam melaksanakan kebijakannya ternyata lebih memilih kaum intelektual/teknokrat sebagai partner kakuasaan sambil memperkuat Golkar sebagai kendaraan politiknya. Sehingga muncullah para elit baru yang memegang kepemimpinan formal pemerintahan yaitu: pakar ekonomi yang membuat kebijakan, ABRI yang menstabilkan, dan birokrat sebagai pelaksananya. Pada masa awal Orde Baru, mereka memainkan peranan sangat penting. ${ }^{19}$

Dalam rangka pembangunan ekonomi, Soeharto telah menunjuk lima ekonom lulusan Amerika Serikat, yaitu: Widjojo Nitisastro, Emil Salim, Ali Wardhana, Mohammad Sadli dan Subroto. Di samping itu ada Radius Prawiro, J.B. Sumarlin dan Arifin Siregar. Pemikiran mereka dalam bidang ekonomi sesuai dengan garis Amerika. Merekalah yang telah merancang perekonomian Indonesia. Di sini, yang menarik adalah bahwa Orde Baru menggaet kelompok intelektual, inteligensia, dan teknokrat untuk ikut bertanggungjawab atas terbentuknya sistem politik yang authoritarian. ${ }^{20}$

Sistem ekonomi yang dikembangkan pada masa Orde Baru adalah ekonomi kapitalis yang sangat bergantung pada bantuan Barat. Dalam pembangunan yang bercorak kapitalis inilah terselip westernisasi. Unsur westernisasi adalah suatu resiko yang sulit dihindari oleh Orde Baru dalam rangka modernisasi, sebagai langkah untuk menjauhkan Indonesia dari komunisme. Hal ini memang sejalan dengan kebijakan tujuan pembangunan pada fase awal Orde Baru yaitu: pendidikan di negara-negara Barat, bantuan pemberian saham dan teknik, penanaman modal asing dan pemberian saham, pengaruh media massa, dan pemindahan struktur lembaga dan ekonomi. ${ }^{21}$

\footnotetext{
18 Sebagaimana dikutip dari MacAndrews oleh M. Rusli Karim, op. cit., hal. 66

19 Lihat Eep Saefullah Fatah, Catatan Atas Gagalnya Politik Orde Baru, (Yogyakarta: Pustaka Pelajar, 1998), hal. 52

20 Yahya Muhaimin, op. cit., hal. 122

${ }^{21}$ M. Dawam Rahardjo, Intelektual Inteligensia dan Perilaku Politik Bangsa: Risalah Cendeki-
} 
Dalam bidang politik, rezim Orde Baru dihadapkan pada upaya menciptakan sebuah format politik baru. Upaya ini secara praktis bersamaan dengan tumbuhnya optimisme masyarakat untuk keluar dari kemelut politik pada masa Orde lama. Optimisme akan kehidupan baru yang lebih baik, lebih demokratis, lebih aman, dan lain sebagainya. Format politik yang tercipta antara lain ditandai oleh:

1. Peranan eksekutif (negara) sangat kuat karena dijalankan oleh militer setelah ambruknya Demokrasi Terpimpin dan menjadi satu-satunya pemain utama dalam percaturan politik nasional. Legitimasi peranan mereka dihadirkan melalui konsep dwifungsi ABRI. ${ }^{22}$

2. Upaya membangun sebuah kekuatan organisasi politik sipil sebagai perpanjangan tangan ABRI (dan pemerintahan-karena sampai hampir dua dekade sejak munculnya Orde Baru, sulit membedakan antara pemerintah dan ABRI) dalam politik. Organisasi politik itu adalah Golkar. Maka dengan segala cara dilakukan untuk meraksasakan Golkar dan mengebiri partai-partai politik lain. Bagi ABRI, Golkar bernilai sangat strategis, karena selain bisa menjadi mesin legitimasi politik juga dapat berperan sebagai perangkat -dan kemudian mitra-politik militer dalam menegakkan stabilitas politik, menjalankan pembangunan ekonomi demi pertumbuhan, dan membangun model pemerintahan Orde Baru yang bercirikan sentralisasi dan depolitisasi..$^{23}$ Upaya ini berhasil setelah pemilu 1971 dengan terciptanya sistem kepartaian yang hegemonik.

3. Penjinakan radikalisme dalam politik melalui proses depolitisasi massa dan cara institusionalisasi (institutionalize) dengan pembentukan partaipartai politik, menerapkan konsep floating mass (massa mengambang) dan mengawasi setiap perwakilan politik, termasuk kelompok intelektual pemuda, mahasiswa dan media massa. Sehingga di antaranya la-

awan Muslim, (Bandung: Mizan, 1993), hal. 375

22 Abdul Aziz Thaba, op. cit., hal. 188

23 Lihat M. Syafi'i Anwar, "Politik Akomodasi Negara dan Cendekiawan Muslim Masa Orde Baru: Sebuah Retropeksi dan Refleksi”, dalam ICMI Antara Status Quo dan Demokratisasi, (Bandung: Mizan, 1995), hal. 234-235. Lihat pula Eep Saefullah Fatah, op. cit., hal. 52 
hirlah konsep NKK/ BKK di dalam kehidupan kampus yang mengebiri potensi politis mahasiswa. ${ }^{24}$

4. Tekanan pada pendekatan keamanan (security approach) dibandingkan dengan pendekatan kesejahteraan (prosperity approach) dalam pembangunan politik untuk menciptakan stabilitas politik. ${ }^{25}$

5. Menggalang dukungan masyarakat melalui organisasi-organisasi sosial dalam jaringan korporatis. Korporatisme negara menyerap semua unsur dalam masyarakat, menjadikan birokrasi "ibarat gurita yang sangat perkasa, memangsa semua lawannya" sedangkan posisi masyarakat lemah. Di dalam setiap pengambilan keputusan politik nasional, masyarakat hampir belum pernah dilibatkan. Masyarakat dilibatkan hanya pada tahap pelaksanaannya. Masyarakat pun sangat mudah dimobilisasikan untuk memberikan dukungan kepada setiap kebijakan pemerintah. ${ }^{26}$

Menurut King (1982), ada lima ciri menonjol Orde Baru, jika dibandingkan dengan Orde Lama, yaitu: pertama, peningkatan pemusatan atau konsolidasi kekuasaan yang berhasil mengakhiri dualisme kekuasaan. Kedua, lebih memberikan perhatian untuk menciptakan persatuan kekuatan-kekuatan yang saling berebut setelah PKI dihancurkan. Ketiga, pragmatisme dan konservatisme sosial. Keempat, penggunaan kekerasan secara meluas untuk menentang kelompok yang tidak mau digulingkan yang menandai bermulanya yang baru dan berakhirnya yang lama. Kelima, bergantung pada bantuan dana dari luar negeri yang memungkinkan adanya pengawasan luar terhadap sumber-sumber ekonomi yang tidak mencukupi. Sehingga dengan ciri-ciri ini rezim Orde Baru adalah rezim authoritarian birocratic, yang memperkuat dasar legitimasi yang terdiri dari berbagai prinsip tradisional, karismatik, legal dan rasional subtantif dan keberhasilan teknikal. ${ }^{27}$

${ }^{24}$ M. Rusli Karim, op. cit., hal. 60 Lihat pula Anders Uhlin, op. cit., hal. 59

25 Pendekatan seperti ini berakibat pada: penghargaan terhadap HAM kurang terjamin, ada kecenderungan untuk menciptakan homogenitas pemikiran, berkembangnya nepotisme, dan tuduhan adanya invisible hand (tangan-tangan setan) atas kejadian yang tidak mendukung harmoni. Susetiawan,"Harmoni, Stabilitas Politik dan Kritik Sosial", Kritik Sosial dalam Wacana Pembangunan, (Yogyakarta: UII Press, 1997), hal. 17-18

26 Abdul Aziz Thaba, op. cit., hal. 188-189

27 Sebagaimana dikutip oleh M. Rusli Karim, op. cit., hal. 68 
Dalam perspektif yang agak berbeda, William Liddle berpendapat bahwa ada tiga karakteristik menonjol yang membuat orang optimis akan keberhasilan rezim Orde Baru, yaitu: pertama, menonjolnya golongan teknokrat, yaitu para pakar ekonomi lulusan Amerika Serikat. Kedua, dominannya ABRI pada politik tingkat tinggi dan tiadanya oposisi sehingga stabilitas politik dapat terjamin. Ketiga, birokrasi yang kompak. ${ }^{28}$ Bahkan Liddle menambahkan bahwa pada awal tahun 1990-an kestabilan politik dan pembangunan ekonomi sudah mantap. Sehingga ia kemudian memandang sudah saatnya untuk memikirkan kembali masalah demokratisasi. ${ }^{29}$

Sedangkan Herbert Feith, menamakan rezim Orde Baru dengan repressive developmentalist, yaitu suatu rezim-rezim negara kuat yang terlibat dalam pemberian kemudahan pertumbuhan kapitalis yang pesat, kebanyakan dengan industrialisasi. Ciri khusus bentuk ideologis rezim ini mengandung tiga unsur: developmentalis-teknokratik, nasionalis dan militeristik.

Pengawasan politik yang dilakukan oleh rezim Orde Baru, oleh Feith digambarkan sebagai pengawasan yang mencakup tiga langkah: penghapusan besar-besaran pusat-pusat kekuatan yang ada di luar pemerintah; memperketat pengawasan kepemimpinan pemerintah terhadap badan-badan kenegaraan dan terhadap masyarakat; menetralisasi kelompok-kelompok "musuh" yang potensial dengan cara menyebarkan perlindungan (patronage) bagi kelompok yang dianggap penting. ${ }^{30}$

Adapun Shin berpendapat, bahwa Orde Baru adalah merupakan suatu negara birokratik yang dibentuk dengan cara demobilisasi dan depolitisasi, intimidasi rakyat dan pembersihan birokrasi dari pengaruh luar, terutama partai politik dan kelompok agama. Partai politik dan kelompok kepentingan pada umumnya hanya memainkan peran kedua (secondary) dan tidak lagi mempunyai kekuatan. Yang terjadi kemudian adalah pemusatan (sentralisasi) kekuasaan. ${ }^{31}$ Langkah semacam ini cenderung memisahkan negara dari masyarakat,

28 William Liddle, "The Politics and Development Policy" dalam World Development, Vol. 20, 1992, hal. 130 dalam M. Rusli Karim, Ibid., hal. 62

29 William Liddle, Islam, Politik dan Moderniasi (terj.), (Jakarta: Pustaka Sinar Harapan, 1997), hal. 211

30 Sebagaimana dikutip oleh M. Rusli Karim dari Brown, The State and Ethnic Politics in Southeast Asia, (London: Routledge, 1994)

31 Model struktur kekuasaan yang sentralistrik pada masa Orde Baru disinyalir beber- 
sehingga tidak ada kekuatan yang bisa menuntut accountability negara, karena kuatnya dominasi negara atas masyarakat. ${ }^{32}$

Sebenarnya Orde Baru tidak memiliki legitimasi politik yang cukup kuat untuk berkuasa namun ia telah mampu membangun pemerintahan yang kuat dan efektif. Hal itu disebabkan oleh empat sumber, yaitu: pertama, keleluasaan Orde Baru untuk menggunakan mekanisme kekerasan, baik kekerasan militer maupun kekerasan hukum. Kedua, klientelisme ekonomi yang berhasil dilakukan berkat melimpahnya sumberdaya ekonomi dari hasil ekspor minyak dan hasil alam lain. Ketiga, ideologisasi definisi partikularistik terhadap segala kehidupan bernegara untuk melegitimasi otoritarianismenya. Definisi partikularistik tentang demokrasi pancasila, hak azasi manusia, tanggung jawab warga negara dan lain-lain, telah membangun keabsahan moral rezim Orde Baru. Keempat, jaringan korporatisme negara yang menyalurkan partisipasi masyarakat menjadi mobilisasi yang terkontrol..$^{33}$

Kebijakan dan situasi politik yang demikian itu, tidak memberi tempat bagi umat Islam untuk lebih mengekspresikan sisi ekonomi Islam dalam aktivitas ekonominya. Umat Islam tertutup aksesnya dari berhubungan lebih intensif dengan negara-negara muslim lainnya, terutama timur tengah, karena kiblat ekonomi Orde Baru adalah Barat yang direpresentasi oleh Amerika. Akibatnya, Indonesia jauh tertinggal di banding negara muslim lain, misalnya Malaysia yang negara tetangga terdekat dan serumpun. Hal ini tidak lepas dari kebijakan politik ekonomi yang dimainkan oleh pemerintah Orde Baru dalam menyikapi Islam dan berbagai aspek ajarannya yang lebih dianggap sebagai ancaman (is-

apa tokoh sebagai akibat dari pengaruh budaya Jawa. Penguasa Orde Baru menempatkan dirinya sebagai penguasa dalam konsepsi Jawa, yaitu bahwa kekuasaannya memili ki sifat kodrati atau ilahiah. Sifat kodrati tersebut sejalan dengan konsep tentang lingkungan yang menginginkan keteraturan dan keselarasan. Akibatnya, struktur kekuasaan disusun sedemikian rupa sehingga bersifat sentralistrik pada penguasa tertinggi. Lihat Revrisond Baswir dkk. Pembangunan Tanpa Perasaan Evaluasi Pemenuhan Hak Ekonomi Sosial Budaya Orde Baru, (Yogyakarta: Pustaka Pelajar dan ELSAM, dan IDEA, 1999), hal. 240. Pendapat serupa dikemukakan Franz Magnis Suseno.

32 Anders Uhlin, Indonesia and the "Third Wave of Democratization": The Indonesian ProDemocracy Movement in a Changing World,(terj. Indonesianya Oposisi Berserak), (Bandung: Mizan, 1998), hal. 44

33 Pratikno, "hubungan Pusat Daerah Gelombang Ketiga: sosok Otonomi daerah di Indonesia Pasca Soeharto", UNISIA, No. 39/XXII/III/1999, hal. 71-72 
lamophobia). Maka tidak mengherankan, Malaysia lebih dulu hampir 10 tahun mendirikan perbankan Islam ${ }^{34}$ dengan dukungan regulasi pemerintah yang sangat mencukupi. Sedangkan perbankan Islam di Indonesia beroperasi baru mulai tahun 1992 yaitu dengan berdirinya Bank Muamalat Indonesia (BMI) yang hadir tanpa dukungan peraturan perundangan yang memadai. Sebagai Bank Islam pertama di Indonesia, BMI pun belum memakai nama bank Syariah tetapi sebagai bank bagi hasil, karena memang belum ada payung hukum yang menjadi naungan berdirinya bank Syariah di Indonesia.

Sampai berakhirnya Orde Baru pada tahun 1998, perkembangan praktik ekonomi Islam di Indonesia, khususnya pada bidang bank Syariah dan asuransi Syariah di Indonesia dapat dikatakan jalan di tempat. ${ }^{35}$ Penyebab utamanya adalah minimnya dukungan politis pemerintah untuk mengembangkan ekonomi Islam, misalnya berwujud payung hukum yang jelas untuk industri perbankan dan asuransi Syariah. Satu-satunya naungan hukum, yakni Undang-Undang (UU) No. 7 Tahun 1992 tentang Perbankan dan Peraturan Pemerintah (PP) No. 72 Tahun 1992, Pasal 6 menentukan bahwa bank umum dan Bank Perkreditan Rakyat (BPR) yang kegiatannya berasaskan prinsip bagi hasil, tidak diperkenankan melakukan usaha yang tidak berasaskan prinsip bagi hasil. Begitu juga sebaliknya. Ini bermakna, tidak ada peluang untuk membuka Syariah windows di bank konvensional. ${ }^{36}$

Di sisi lain, regulasi lebih komprehensif yang mengatur tentang bank Syariah masih sangat terbatas, sehingga dalam banyak hal bank Syariah harus patuh

34 Lembaga-lembaga keuangan yang didirikan dengan berlandaskan prinsip syariah mempunyai dua tujuan utama, yaitu: (1) Membangun sosioekonomi yang berlandaskan keadilan dan menganggap aktivitas ekonomi sebagai cara mencapai tujuan dan bukannya tujuan itu sendiri. (2) Islam menekankan persoalan perkembangan ekonomi dan melihatnya sebagai bagian yang terpenting daripada masalah-masalah lain yang lebih besar. Pertumbuhan ekonomi tidak dapat dipisahkan dari perkembangan manusia secara total. Fungsi utama Islam adalah untuk memandu perkembangan manusia ke arah landasan yang benar. Saad al-Harran (1995), Leading Issues in Islamic Banking and Finance. Selangor: Pelanduk Publication Sdn. Bhd., hal. viii.

35 Sofyan S. Harahap dan Yuswar Z. Basri (2004), “The History and Development of Islamic Banking in Indonesia, 1990-2002", dalam Bala Shanmugan et al. (eds.), Islamic Banking: An International Perspective. Serdang: Universti Putra Malaysia Press, hal. 39.

36 Muhammad Amin Suma (2003), “Jaminan Perundang-undangan Tentang Eksistensi Lembaga Keuangan Syariah di Indonesia”, Jurnal al-Mawarid, Edisi X, hal. 9. 
pada peraturan perbankan konvensional. Oleh karena itu, manajemen BMI cenderung untuk meniru produk dan jasa perbankan konvensional yang kemudian "diislamkan". Ini menyebabkan jenis produk dan jasa yang ditawarkan oleh BMI terbatas, sebab tidak semua produk dan jasa bank konvensional bisa "diislamkan". Akibatnya tidak semua keperluan masyarakat dapat dipenuhi. ${ }^{37}$

Keberhasilan pendirian BMI telah mengilhami kesadaran masyarakat untuk mengamalkan ekonomi Syariah, sehingga sejak itu mulai didirikan lembaga keuangan Syariah mikro yaitu Bank Perkreditan Rakyat Syariah (BPRS, kini singkatannya menjadi Bank Pembiayaan Rakyat Syariah) dan Baitul Mal Wattamwil ${ }^{38}$ (BMT). ${ }^{39}$ Perkembangan BMT relatif lebih pesat dibanding bank Syariah, karena lebih simpelnya proses pendirian dan pengoperasiannya, sehingga jumlah BMT di Indonesia pada akhir pemerintahan Orde Baru mencapai 1000-an. Pesatnya perkembangan BMT tersebut tidak lepas dari gencarnya ICMI melakukan edukasi pada berbagai elemen masyarakat untuk pendirian dan pengoperasian BMT di berbagai wilayah Indonesia.

\section{Politik Era Reformasi dan Ekonomi Islam}

Perubahan dipahami sebagai sesuatu yang terus menerus terjadi, phanta rei, semuanya mengalir dan berubah. Sejarah mengenal perubahan-perubahan besar. Demikian juga dalam sejarah Indonesia, terdapat perubahan-perubahan besar. Di antaranya adalah Proklamasi Kemerdekaan pada 17 Agustus 1945, dan gerakan reformasi 20 Mei 1998 yang kemudian melengserkan Soeharto pada 21

37 Muhammad Amin Suma (2003), op.cit., hal. 10.

38 Istilah BMT berasal dari dua suku kata yaitu bayt al-mal dan bayt al-tamwil. Istilah bayt al-mal berasal dari kata bayt dan al-mal. Bayt artinya bangunan atau rumah, sedangkan al-mal berarti harta benda dan kekayaan. Jadi secara etimologis (harfiyyah) atau segi bahasa berarti, baytul mal berarti rumah kekayaan. Namun demikian kata bayt al-mal biasa diartikan sebagai perbendaharaan (umum atau negara). Sementara bayt al-tamwil berasal dari kata bayt artinya rumah, dan al-tamwil merupakan bentuk masdar yang artinya pengumpulan harta. Jadi bayt al-tamwil dapat diartikan sebagai rumah pengumpulan harta atau dapat diidentikkan dengan bank pada zaman modern ini. Dalam konteks Indonesia, BMT memiliki makna yang khas, yaitu lembaga keuangan mikro Syariah untuk membantu usaha ekonomi rakyat kecil, yang beranggotakan perorangan atau badan hukum, yang dijalankan berdasarkan prinsip Syariah dan prinsip koperasi.

39 Adiwarman Karim (2004), Bank Islam, Analisis Figh dan Keuangan. Jakarta: PT Raja Grafindo Persada, hal. 24-25; Heri Sudarsono (2004), op.cit., hal. 32 dan 83-84. 
Mei 1998. Peristiwa ini menandai berakhirnya Orde Baru ${ }^{40}$ dan dimasukinya era baru yaitu Era Reformasi. Ini artinya era kepemimpinan Soeharto (Orde Baru) telah berakhir.

Pasca turunnya Soeharto, terjadi perubahan-perubahan yang drastis dan dramatis dalam kehidupan sosial politik Indonesia. Gejala-gejala perubahan itu ditandai dengan fenomena-fenomena berikut:

1. Redefinisi Hak-Hak Politik.

Pasca turunnya Soeharto, rakyat mulai melakukan redefinisi hak-hak politiknya yang pada mulanya terpasung oleh Orde Baru. Di antaranya yang paling menonjol adalah hak kebebasan. Dalam konteks ini, kebebasan berpolitik, kebebasan berdemonstrasi, pembebasan tahanan politik, kebebasan menjalankan ajaran agama, liberasi media massa, dan lain-lain menjadi fenomena umum.

2. Ledakan Partisipasi

Di tingkat elit, ledakan partisipasi ditandai dengan terjadinya politisasi, aliansi-realiansi, oposisi, protes, dan perlawanan politik. Wujudnya beragam: maraknya kelompok oposisi, partai tumbuh bak jamur di musim hujan, pers mengalami politisasi sekaligus liberasi. Sedangkan pada tingkat massa, ledakan partisipasi terjadi dalam bentuk gerakan massa dan amuk. Dan seringkali ledakan partisipasi model ini cenderung bersifat destruktif dan anarkis.

3. Surplus Percaya Diri pada Publik.

Tidak ada yang menyangka Soeharto bakal jatuh secepat itu. Menurut Anders Uhlin, krisis ekonomi, meski bukan satu-satunya adalah faktor dan momentum terpenting dalam kejatuhan Soeharto. Soeharto tidak dapat menikmati lebih lama lagi legitimasi yang "dibeli" dengan pertumbuhan ekonomi. Tekanan-tekanan IMF semakin memperburuk krisis ekonomi yang paling dahsyat sepanjang sejarah perjalanan

${ }^{40}$ Menurut Amien Rais, runtuhnya Orde Baru disebabkan oleh dua sebab utama yaitu: sistem sosial, politik, dan ekonomi yang dibangun ternyata tidak lagi tenable dan sustainable karena tidak menjamin adanya akuntabilitas dan kreativitas. Kedua, struktur mental yang korup dan predatorik ternyata tumbuh semakin parah dari waktu ke waktu selama kurun waktu tiga puluh tahun terakhir ini. Amien Rais, "Pilihan dalam Mengatasi Krisis: Status Quo atau Reformasi", dalam Tim KAHMI JAYA, Indonesia di simpang Jalan, (Bandung: Mizan, 1998), hal. 18 
bangsa Indonesia. ${ }^{41}$ Ketika mahasiswa memimpin demonstrasi massa menentang Soeharto dan pemimpin-pemimpin Islam mendesak soeharto untuk mengundurkan diri, elit militer meninggalkan Soeharto untuk melindungi kepentingannya sendiri, akhirnya jatuhlah Soeharto. ${ }^{42}$ Tidak ada yang menyangka bahwa Soeharto akan jatuh secepat itu. Bahkan Affan Gaffar menyatakan bahwa sampai Maret 1998, peluang untuk suksesi hampir sama sekali tidak ada. ${ }^{43}$ Namun kenyataannya Soeharto jatuh secara dramatis. ${ }^{44}$ Jatuhnya Soeharto telah melahirkan kepercayaan diri yang sangat besar di kalangan publik. Ini adalah realitas positif yang mesti disyukuri sekaligus diwaspadai, jangan sampai kebablasan ke anarkhi.

4. Delegitimasi dan Krisis Kredibilitas Kekuasaan

Jatuhnya Soeharto membuka peluang bagi berkembangnya agenda delegitimasi Orde Baru beserta seluruh instrumen dan institusi politik yang diwariskannya. Naiknya Presiden Habibie-yang selama 20 tahun menjadi pembantu dekat Soeharto-yang memimpin sebuah pemerintahan yang berintikan "orang-orang lama", membuat gelombang delegitimasi kekuasaan justru makin menguat sepeninggal Soeharto.

5. Menegasnya Fragmentasi dan Disintegrasi Politik.

Di era Soeharto yang terjadi adalah kerangka politik penyeragaman baik di tingkat elit maupun massa. Penyeragaman tidak hanya pada bahasa tetapi juga pada berbagai dimensi kehidupan, seperti kebudayaan dan sistem sosial politik. Ide dan nilai yang ditransfer dari

41 Abd. Rohim Ghazali, Keharusan Reformasi Politik: Pengantar Editor", dalam Kapan Badai Akan Berlalu Suara-Suara Kritis Cendekiawan Menghendaki Perubahan, (Bandung: Mizan, 1998), hal. 17

42 Anders Uhlin, "Demokratisasi di Indonesia: Peluang dan Hambatan", dalam Wacana, Edisi 2, Tahun I, 1999, hal. 81

43 Affan Gaffar, "Reformasi Politik harus digelindingkan Terus", dalam Abd. Rohim Gahzali, op. cit., hal. 102

44 Menurut Greg Barton faktor runtuhnya Soeharto adalah pertama, terjadinya krisis moneter yang menaikkan tekanan bagi rezim Orde Baru; kedua, sikap menahan diri dan profesionalisme yang ditinjukkan oleh sebagian besar prajurit ABRI, yang tetap mematuhi perintah dari Panglima ABRI; ketiga, peristiwa tragis pada 12 dan 14 Mei yang meminta korban nyawa dan ekonomi. Greg Barton, "Kemenangan Civil Society", dalam Politik Demi Tahun Nasionalisme Religius di Indonesia, (Bandung: Pustaka Hidayah, 1999), hal. 377 
pusat kekuasaan pemerintah merupakan intervensi terhadap berbagai dimensi kehidupan yang sah dan kemudian digantikan dengan yang baru yang bersifat seragam di seluruh Indonesia. Penyeragaman ini tanpa memberi ruang yang cukup bagi perkembangan dan ciri khas daerah. ${ }^{45}$ Faksionalisme tidak pernah bisa mengemuka di masa itu. ${ }^{46}$ Sepeninggal Soeharto, faksionalisme mengemuka tanpa bisa ditahan. Pada saat yang sama disintegrasi politik di antara berbagai kelompok menjadi gejala sangat menonjol. ${ }^{47}$

Dalam bidang politik, reformasi menuntut diimplementasikannya kebebasan yang seluas-luasnya untuk berserikat, berkumpul, dan menyampaikan pendapat secara lisan maupun tulisan, sesuai dengan pasal 28 UUD 1945. Iklim reformasi telah melahirkan dinamika politik dan kekuasaan yang semakin kompleks-problematis. Dengan jelas kita bisa melihat bangkitnya politik kekuasaan dan politik kekuatan. Pendirian partai politik, termasuk partai Islam dalam jumlah yang sangat banyak sehingga mencapai kurang lebih dua ratus buah tentunya semuanya dengan dalih atau kehendak untuk berkuasa atau turut berpartisipasi dalam kekuasaan..$^{48}$ Ini menunjukkan adanya dinamika baru dalam dunia perpolitikan di Indonesia, walau ada yang menanggapinya dengan rasa prihatin. ${ }^{49}$ Fenomena ini merupakan bagian dari euphoria kebebasan

45 Irwan Abdullah, "Kondisi Sosial dan Bayangan Disintegrasi", Kompas, (Jakarta), 28 Juni 2000, hal. 33

46 Oleh karena iru, menurut Sandra Moniaga, era reformasi saaat inilah momentum yang tepat untuk meninjau kembali kesalahan-kesalahan tersebut. Reformasi yang kini sedang bergulir tidak akan pernah mencapai tatanan politik yang menghormati hak asasi manusia dan demokratis apabila eksistensi dan aspirasi masyarakat adat (daerah) tidak terakomodasikan di dalamnya. Sandra Moniaga, Menggugat Posisi Masyarakat Adat Terhadap Negara, (Yogyakarta: Pustaka Pelajar, 1999), hal. ix

47 Eep Saefullah Fatah, Membangun Oposisi Agenda-Agenda Perubahan Politik Masa Depan, (Bandung: PT Remaja Rosdakarya, 1999), hal. xx-xxiii

48 Soemarno Dipodisastro, "Manusia, Politik dan Kekuasaan", dalam Ade Kamaluddin dkk. (ed.), Menuju Masyarakat Cita: Refleksi Atas Persoalan-Persoalan Kebangsaan, (Jakarta: Badko HMI Maliarja, 1999), hal. 28

49 Zawawi Imron, Gumam-Gumam Dari Dusun, Indonesia di Mata Seorang Santri, (Bandung: Pustaka Hidayah, 2000), hal. 68 
Tuntutan dan aspirasi reformasi total dalam kehidupan berbangsa, ${ }^{50}$ bernegara dan bermasyarakat bukanlah persoalan mudah. Tapi jika ada political will dari pemerintah yang tengah berkuasa, ${ }^{51}$ dan juga ada dukungan dari segenap masyarakat Indonesia, tentu saja hal itu bisa diupayakan. Pemerintahan era reformasi telah merespon, mengakomodasi tuntutan itu dan telah mendapatkan bentuknya yang konstitusional-demokratis.

Dalam kaitannya dengan pemulihan ekonomi bangsa, maka fondasi yang kokoh hanya dapat dicapai bila situasi politik stabil. Bila pemulihan ekonomi diumpamakan sebagai suatu bangunan maka bangunan itu harus berdiri di atas fondasi yang kuat (hukum). Fondasi itu hanya kuat kalau tanah sekitarnya tidak labil (stabilitas politik). Demikian antara lain hubungan ekonomi, hukum dan politik.

Islam sebagai agama mayoritas penduduk Indonesia, merupakan agama yang ajaran-ajarannya bersifat universal dan mencakup segenap aktivitas kehidupan manusia, walau ada sisi kehidupan tertentu yang diatur secara global saja. Namun justru di situlah letak keunggulan Islam sebagai way of life bagi seluruh umat manusia, sehingga Islam senantiasa dapat merespon perkembangan manusia maupun kondisi sosial politik yang mengitarinya. Diakui oleh Ernest Gellner, bahwa Islam adalah agama yang menyokong dalam cita-cita membangun masyarakat madani (civil society), hambatan yang ada hanya terletak pada kesiapan kultural dan ekonomi umatnya. Di sinilah aspek sosial ekonomi umat Islam harus mendapat perhatian khusus.

Bahkan dalam studi yang dilakukan oleh Anders Uhlin terdapat suatu kesimpulan bahwa Islam di Indonesia adalah agama yang jauh dari menjadi ancaman bagi demokrasi, bahkan Islam dapat menjadi satu faktor kuat dalam

50 Menurut Frans Seda fokus proses reformasi adalah pembentukan dan pembinaan Good Governance (penyelenggaraan pemerintahan secara baik dan benar). Karena dengan Good Governance maka reformasi politik, ekonomi dan hukum serta prosesnya dapat berlangsung secara efektif. Frans Seda, "Sebuah Dialog tentang Reformasi”, Kompas, (Jakarta), 10 Juli 1998

51 Reformasi pada awal-awal permulaannya mengalami kesulitan karena kurangnya political will di kalangan pemerintahan dalam rangka mengadakan reformasi ekonomi dan politik. Amien Rais, “Dua Langkah Reformasi yang Harus Ditempuh: Diperlukan Ketulusan dan Kesungguhan", dalam Abd. Rohim Ghazali, Keharusan Reformasi Politik: Pengantar Editor", dalam Kapan Badai Akan Berlalu Suara-Suara Kritis Cendekiawan Menghendaki Perubahan, (Bandung: Mizan, 1998), hal. 166 
mendukung demokrasi di Indonesia. ${ }^{52}$ Kondisi perpolitikan era Reformasi yang kondusif untuk pengembangan ekonomi Islam tersebut telah dimanfaatkan dengan baik oleh umat Islam, sehingga lahirlah kebijakan dan regulasi yang mendukung terwujudnya praktik ekonomi Islam yang berpayung hukum jelas dan mendapat legitimasi yang kuat dari pemerintah.

Penguasa politik era Reformasi lebih terbuka terhadap aspirasi masyarakat. Respon terhadap aspirasi tersebut juga lebih bersifat akomodatif dan kooperatif walau tetap mengendepankan prinsip bhinneka tunggal ika. Walaupun situasi perpolitikan di era reformasi sangat dinamis, akan tetapi tidak menjadi hambatan yang berarti bagi pengembangan ekonomi Islam. Hal ini misalnya terlihat dari lahirnya Undang-undang Nomor 10 Tahun 1998 dan Undang-undang Nomor 23 Tahun 1999. Dua regulasi tersebut telah mendorong lahirnya booming perbankan syariah mulai 1999. Setelah diundangkannya payung hukum tersebut, walaupun belum berbentuk UU Perbankan Syariah secara tersendiri, tetapi telah menjadi cukup amunisi untuk lahirnya akselerasi perkembangan perbankan Syariah di Indonesia.

Pemerintah era reformasi tidak hanya membuat regulasi yang memungkinkan praktik ekonomi Islam semakin berkembang, tetapi juga mendirikan bank Syariah yang notebenenya berkategori BUMN. Hal ini misalnya pada tahun 1999, pemerintah mendirikan Bank Syariah Mandiri (BSM) yang modal inti terbesarnya dari Bank Mandiri yang nota benenya bank BUMN, selanjutnya BRI Syariah yang modal inti terbesarnya dari Bank BRI yang nota benenya bank BUMN, BNI Syariah yang modal inti terbesarnya dari BNI 45 yang nota benenya bank BUMN yang juga berplat merah, pegadaian Syariah yang berada dibawah perum pegadaian yang merupakan BUMN juga, dan lain-lain.

Di sektor kuangan publik Islam, pemerintah era reformasi telah mengundangkan UU No. 38 Tahun 1999 tentang Zakat. Diundangkannya UU Zakat menunjukkan politik ekonomi Islam dalam ranah keuangan publik pemerintah RI cukup akomodatif terhadap kebutuhan umat Islam untuk melaksanakan rukun Islam yang ke-3. Pada tahun 2004, juga lahir UU No. 41 Tahun 2004 tentang Wakaf. Pemerintah juga telah menetapkan Peraturan Pemerintah Nomor 42 tahun 2006 tentang Pelaksanaan Undang-undang Nomor 41 tahun 2004, ditambah Kepmen Nomor 04 Tahun 2009 tentang Administrasi Wakaf Uang.

${ }^{52}$ Untuk lebih lengkapnya lihat Anders Uhlin, op. cit., hal. 67-87 
Selanjutnya disahkan UU Nomor 19 tahun 2008 tentang Surat Berharga Syariah Negara (SBSN) pada 7 Mei 2008. ${ }^{53}$ Lahirnya UU SBSN memberikan harapan di tengah APBN yang selalu defisit untuk bisa mendorong tersedianya sumber keuangan alternatif bagi negara. UU SBSN saat ini telah menjadi landasan hukum bagi pemerintah RI untuk penerbitan sukuk negara guna menarik dana dari investor yang menginginkan instrumen investasi yang sesuai Syariah.

Regulasi yang mendapat perhatian luas adalah diundangkannya UU No. 21 Tahun 2008 tentang Perbankan Syariah pada 17 Juni 2008. Dengan UU Perbankan Syariah ini makin memperkuat landasan hukum perbankan Syariah sehingga dapat setara dengan bank konvensional. Eksistensi Dewan Syariah Nasional Majelis Ulama Indonesia (DSN MUI) berdiri pada tanggal 10 Februari 1999 sebagai lembaga yang memiliki otoritas kuat dalam penentuan dan penjagaan penerapan prinsip Syariah dalam operasional di lembaga keuangan Syariah, baik perbankan Syariah, asuransi Syariah dan lain-lain diperkuat UU No.21 Tahun 2008 tentang Perbankan Syariah pasal 32 dan UU No. 40 Th 2007 tentang Perseroan Terbatas pasal 109 yang pada intinya bahwa Dewan Pengawas Syariah wajib dibentuk di bank Syariah maupun perseroan yang menjalankan kegiatan usaha berdasarkan prinsip syariah. ${ }^{54}$

Untuk mewujudkan kepastian hukum untuk penanganan sengketa yang terkait dengan praktik ekonomi Islam, telah diundangkan Undang-undang Nomor 3 Tahun 2006 tentang perubahan atas Undang-undang Nomor 7 Tahun 1989 tentang Peradilan Agama telah memberikan arah baru bagi kompetensi Peradilan Agama. Semula kompetensi Pengadilan Agama identik dengan NTCR (Nikah, Talak, Cerai dan Rujuk), akan tetapi dengan adanya UU Nomor 3 Tahun 2006 tersebut, kompetensi Peradilan Agama bertambah, khususnya sebagaimana yang tersebut dalam pasal 49 huruf i, yakni Pengadilan agama bertugas dan berwenang memeriksa, memutus, dan menyelesaikan perkara di tingkat pertama antara orang-orang yang beragama Islam di bidang ekonomi Syariah.

Ekonomi Syariah yang dimaksud dalam pasal 49 huruf i, penjelasannya mencakup (a) bank syari'ah; (b). lembaga keuangan mikro syari'ah. (c). asuran-

53 Republika, 18 Juni 2008

54 Nur Kholis, "Potret Politik Ekonomi Islam di Indonesia Era Reformasi", Jurnal MILLAH, Magister Studi Islam UII (accredited), Vol. X, No. 2, Februari 2011. 
si syari'ah; (d). reasuransi syari'ah; (e). Reksa dana syari'ah; (f). obligasi syari'ah dan surat berharga berjangka menengah syari'ah; (g). sekuritas syari'ah; (h). pembiayaan syari'ah; (i). Pegadaian syari'ah; (j). dana pensiun lembaga keuangan syari'ah; dan (k). bisnis syari' ah..$^{55}$

Masih banyak lagi praktik ekonomi Islam yang berkembang pesat di era reformasi sebagai dampak dari semakin kondusifnya situasi dan kondisi perpolitikan di Indonesia, misalnya gerakan nasional wakaf tunai dimotori oleh Presiden Susilo Bambang Yudhoyono di Istana Negara Jakarta pada 8 Januari 2010, ${ }^{56}$ semakin berkembangnya instrumen syariah di Pasar Modal Syariah yang disediakan oleh Bursa Efek Indonesia (BEI), semakin kuatnya eksistensi asuransi Syariah secara regulasi, dan lain-lain. Tahun depan, 2014, Indonesia akan menjalani prosesi suksesi kepemimpinan nasional. Bahkan tahun 2014 disebut sebagai tahun politik. Pada tahun 2013 ini telah sangat terasa kompetisi antar partai dan tokoh-tokohnya untuk memenangkan percaturan politik nasional. Kondisi perpolitikan yang telah kondusif pada era reformasi perlu terus dijaga dan bahkan perlu ditingkatkan untuk menunjang percepatan pertumbuhan ekonomi, khususnya perkembangan ekonomi Islam di Indonesia dalam rangka mewujudkan kehidupan masyarakat Indonesia yang adil dan berkatakter. ${ }^{57}$

\section{E. Penutup}

Berdasarkan deskripsi di atas, sangat jelas terlihat pengaruh situasi dan kondisi politik suatu era tertentu terhadap perkembangan ekonomi Islam. Perubahan situasi dan kondisi politik akan berpengaruh terhadap kehidupan ekonomi, khususnya perkembangan ekonomi Islam. Dengan demikian, situasi dan kondisi politik pemerintahan yang kondusif sangat diperlukan untuk semakin berkembangnya praktik ekonomi Islam dalam berbagai bidangnya, baik keuangan dan perbankan Islam maupun sektor riil dan sosialnya. Perkembang-

55 Lihat penjelasan UU No. 3 Tahun 2006 pasal 49 huruf $i$.

56 http:/ / www.indonesia.go.id/id/ 08-01-2010, diakses pada 6 Juni 2013; http:/ / www. dakwatuna.com/ diakses pada 6 Juni 2013.

57 Nur Kholis, Praktik Ekonomi Islam di Indonesia dan Implikasinya bagi Pembangunan Karakter Bangsa, AHKAM, Jurnal Hukum Islam, Vol.13, NO. 02, ISSN 1411-271X, Nop 2011 
an dan pertumbuhan praktik ekonomi Islam di Indonesia dapat dikatakan sangat pesat setelah situasi dan kondisi perpolitikan di era reformasi menjadi kondusif dan dukungan pemerintah dalam bentuk politik ekonomi yang pro pada prinsip-prinsip ekonomi Islam. Perkembangan pesat tersebut dapat terlihat dari sisi perkembangan jumlah aset maupun bidang ekonomi yang menerapkan sistem ekonomi Islam, seperti perbankan Syariah, asuransi Syariah, sukuk, pasar modal Syariah, keuangan publik, dan lain-lain. Kenyataan tersebut sangat berbeda dibanding dengan perkembangan praktik ekonomi Islam pada era Orde Baru yang pemerintahannya mewujudkan lahirnya situasi dan kondisi politik yang cenderung represif dan menjadikan Islam sebagai enemy.

Realitas yang demikian baik pada era reformasi, memberikan harapan besar yang menumbuhkan optimisme bagi umat Islam untuk terus berupaya mengembangkan ekonomi Islam di Indonesia, terlebih lagi dukungan pemerintah yang diwujudkan dalam berbagai regulasi dan political will semakin nyata mendukung pengembangan ekonomi Islam di Indonesia. Untuk itu, walau kini situasi politik mulai menghangat menjelang pemilihan umum 2014, diperlukan usaha bersama untuk menjaga situasi dan kondisi perpolitikan yang kondusif pada transisi kepemimpinan nasional tahun 2014 nanti. Transisi kepemimpinan nasional yang berlangsung damai dan memuaskan berbagai pihak yang berkompetisi semoga menjadi realitas yang mewujud pada masa mendatang, dengan begitu situasi dan kondisi politik akan tetap kondusif untuk praktik ekonomi Islam yang lebih luas demi mengakselerasi terwujudnya tatanan ekonomi Indonesia yang berkeadilan dan mensejahterakan.

\section{DAFTAR PUSTAKA}

Abd. Rohim Ghazali, Keharusan Reformasi Politik: Pengantar Editor", dalam Kapan Badai Akan Berlalu Suara-Suara Kritis Cendekiawan Menghendaki Perubahan, (Bandung: Mizan, 1998)

Abdul Aziz Thaba, Islam dan Negara dalam Politik Orde Baru, (Jakarta: Gema Insani Press, 1996)

Acemoglu and Daron dkk, Income and Democracy, (Mimeo: MIT, 2005) , Economic Origins of Dictatorship and Democracy, (Cambridge University Press, 2005) 
Adiwarman Karim (2004), Bank Islam, Analisis Figh dan Keuangan. Jakarta: PT RajaGrafindo Persada

Affan Gaffar, "Reformasi Politik harus digelindingkan Terus", dalam Abd. Rohim Gahzali, Keharusan Reformasi Politik: Pengantar Editor", dalam Kapan Badai Akan Berlalu Suara-Suara Kritis Cendekiawan Menghendaki Perubahan, (Bandung: Mizan, 1998)

Al Chaidar, Reformasi Prematur Jawaban Islam Terhadap Reformasi Total, (Jakarta: Darul Falah, 1999)

Amien Rais, "Dua Langkah Reformasi Yang Harus Ditempuh: Diperlukan Ketulusan dan Kesungguhan", dalam Abd. Rohim Ghazali, Keharusan Reformasi Politik: Pengantar Editor", dalam Kapan Badai Akan Berlalu Suara-Suara Kritis Cendekiawan Menghendaki Perubahan, (Bandung: Mizan, 1998)

Amien Rais, "Pilihan dalam Mengatasi Krisis: Status Quo atau Reformasi", dalam Tim KAHMI JAYA, Indonesia di simpang Jalan, (Bandung: Mizan, 1998)

Anders Uhlin, "Demokratisasi di Indonesia: Peluang dan Hambatan", dalam Wacana, Edisi 2, Tahun I, 1999

Anders Uhlin, Indonesia and the "Third Wave of Democratization": The Indonesian Pro-Democracy Movement in a Changing World,(terj. Indonesianya Oposisi Berserak), (Bandung: Mizan, 1998

Anna Both dan Peter Melawley, Ekonomi Orde Baru, (Jakarta: LP3ES, 1981)

Brown, The State and Ethnic Politics in Southeast Asia, (London: Routledge, 1994) Eep Saefullah Fatah, Catatan Atas Gagalnya Politik Orde Baru, (Yogyakarta: Pustaka Pelajar, 1998)

Eep Saefullah Fatah, Membangun Oposisi Agenda-Agenda Perubahan Politik Masa Depan, (Bandung: PT Remaja Rosdakarya, 1999)

Frans Seda, "Sebuah Dialog tentang Reformasi", Kompas, (Jakarta), 10 Juli 1998 Greg Barton, "Kemenangan Civil Society", dalam Politik Demi Tahun Nasionalisme Religius di Indonesia, (Bandung: Pustaka Hidayah, 1999)

Helliwell, John. (1994). “Empirical Linkages Between Democracy and Economic Growth", British Journal of Political Science 24, 225-248.

http://www.dakwatuna.com/ diakses pada 6 Juni 2013. http:/ / www.indonesia.go.id/id/ 08-01-2010, diakses pada 6 Juni 2013 
Irfan Syauqi Beik dalam http:/ /jurnalekis.blogspot.com/2013/01/desain-politik-ekonomi-syariah.html\#sthash.zgeRsgDl.dpuf, diakses 5 Juli 2013

Irwan Abdullah, "Kondisi Sosial dan Bayangan Disintegrasi", Kompas, (Jakarta), 28 Juni 2000

Koentjaraningrat, "Mentalitas Pegawai, Feodalisme, dan Demokrasi", dalam Tim KAHMI JAYA, Jika Rakyat Berkuasa Upaya Membangun Masyarakat Madani dalam Kultur Feodal, (Bandung: Pustaka Hidayah, 1999)

M. Dawam Rahardjo, Intelektual Inteligensia dan Perilaku Politik Bangsa: Risalah Cendekiawan Muslim, (Bandung: Mizan, 1993)

M. Rusli Karim, Negara dan Peminggiran Islam Politik, (Yogyakarta: Tiara Wacana, 1999)

M. Syafi'i Anwar, "Politik Akomodasi Negara dan Cendekiawan Muslim Masa

Orde Baru: Sebuah Retropeksi dan Refleksi", dalam ICMI Antara Status

Quo dan Demokratisasi, (Bandung: Mizan, 1995)

Marwati Poesponegoro dan Nugroho Notosusanto, Sejarah Nasional Indonesia, Jilid VI (Jakarta: Depdikbud dan Balai Pustaka, 1984)

Maswadi Rauf, "Kata Pengantar" dalam buku yang ditulis oleh Ahmad Suhelmi, Soekarno Versus Natsir, (Jakarta: Darul Falah, 1999)

Moeljarto Tjokrowinoto, Pembangunan Dilema dan Tantangannya, (Yogyakarta: Pustaka Pelajar, 1996)

Moh. Mahfud MD, Hukum dan Pilar-Pilar Demokrasi, (Yogyakarta: Gama Media, 1999)

Muhammad Amin Suma (2003), “Jaminan Perundang-undangan Tentang Eksistensi Lembaga Keuangan Syariah di Indonesia", Jurnal al-Mawarid, Edisi X

Nur Kholis, "Potret Politik Ekonomi Islam di Indonesia Era Reformasi", Jurnal MILLAH, Magister Studi Islam UII (accredited), Vol. X, No. 2, Februari 2011.

Praktik Ekonomi Islam di Indonesia dan Implikasinya bagi Pembangunan Karakter Bangsa, AHKAM, Jurnal Hukum Islam, Vol.13, NO. 02, ISSN 1411-271X, Nop 2011

Pratikno, "hubungan Pusat Daerah Gelombang Ketiga: sosok Otonomi daerah di Indonesia Pasca Soeharto", UNISIA, No. 39/XXII/III/1999

Republika, 18 Juni 2008 
Revrisond Baswir dkk. Pembangunan Tanpa Perasaan Evaluasi Pemenuhan Hak Ekonomi Sosial Budaya Orde Baru, (Yogyakarta: Pustaka Pelajar dan ELSAM, dan IDEA, 1999), hal. 240. Pendapat serupa dikemukakan Franz Magnis Suseno.

Robert Barro, "Democracy and Growth", Journal of Economic Growth 1, 1996, $1-27$

Rostow, Irma Adelman, dan Cynthia Taft Morris. Lihat Emil Salim, “Mungkinkah Ada Demokrasi di Indonesia", dalam Elza Peldi Taher (ed.), Demokratisasi Politik, Budaya dan Ekonomi, (Jakarta: Yayasan Paramadina, 1994)

Saad al-Harran, Leading Issues in Islamic Banking and Finance. (Selangor: Pelanduk Publication Sdn. Bhd, 1995)

Sandra Moniaga, Menggugat Posisi Masyarakat Adat Terhadap Negara, (Yogyakarta: Pustaka Pelajar, 1999)

Sarwono Kusumaatmadja dalam, Sketsa Politik Orde Baru, (Bandung: Alumni, 1988)

Soemarno Dipodisastro, "Manusia, Politik dan Kekuasaan", dalam Ade Kamaluddin dkk. (ed.), Menuju Masyarakat Cita: Refleksi Atas Persoalan-Persoalan Kebangsaan, (Jakarta: Badko HMI Maliarja, 1999)

Sofyan S. Harahap dan Yuswar Z. Basri, "The History and Development of Islamic Banking in Indonesia, 1990-2002", dalam Bala Shanmugan et al. (eds.), Islamic Banking: An International Perspective. (Serdang: Universti Putra Malaysia Press, 2004)

Sudarsono, Politik dan pembangunan: Pilihan Masalah (Jakarta: Rajawali Press, 1980)

Susetiawan,"Harmoni, Stabilitas Politik dan Kritik Sosial", Kritik Sosial dalam Wacana Pembangunan, (Yogyakarta: UII Press, 1997)

Torsten Persson dan Guido Tabellini, Democratic Capital: The Nexus Of Political And Economic Change, Massachusetts: NBER Working Paper Series, Working Paper 12175, http:/ / www.nber.org/papers/w12175, 2006

William Liddle, "The Politics and Development Policy" dalam World Development, Vol. 20, 1992

William Liddle, Islam, Politik dan Moderniasi (terj.), (Jakarta: Pustaka Sinar Harapan, 1997) 
204 Millah Vol. XIII, No. 1, Agustus 2013

Yahya Muhaimin, Bisnis dan Politik Kebijaksanaan Ekonomi Indonesia 1950-1980, (Jakarta: LP3ES, 1990)

Zawawi Imron, Gumam-Gumam Dari Dusun, Indonesia di Mata Seorang Santri, (Bandung: Pustaka Hidayah, 2000) 